\title{
Lay Expert（素人専門家）の制度化をめぐって
}

\author{
一一英国 Expert Patient Programme に見るジレンマ——
}

The Institutionalisation of 'Lay Expert':

The Dilemma for the Expert Patient Programme in the UK

松 繁 卓 哉
MATSUSHIGE Takuya

Today the concept of 'lay expert' is increasingly mentioned in public discussions of health care, the judiciary and other areas. In the health care arena, patients and the family are thought to be a person with 'lay expertise'. The Expert Patient Programme (EPP), which has been managed by the National Health Service (NHS) in the UK, aims at institutionalising 'lay expert' in the national healthcare system. This paper illustrates the outline of the EPP and analyses literatures on this scheme for understanding the concept of 'lay expert' and its impact on people's awareness of patient-professional relationship. It is concluded that the EPP works to promote a new concept of 'expert' whilst the new concept can conflict with requirements for the institutionalization of 'expert' in modern society.

\section{1.はじめに}

'Lay Expert（素人専門家）'という語が、様々な領域で近年用いられてきている。一見 する之語義矛盾を感じさせる言葉であるが、同時に、様々な可能性を想起させる語でむあ る。ヘルスケアの領域では、患者（およびその家族）が素人専門家と位置付けられ、患者 が持つ経験・知識に価值を置く姿勢がこの言葉から伺える。このような概念の出現は、い わゆる「患者中心」というスローガンと無縁ではないだろう。

「患者中心」「当事者本位」が今日のヘルスケアをめぐる議論の大きな潮流となっている ことは、我が国のみならず、他の多くの国々に扔いても顕著である。医療の在り方に関す る議論の中で、これらの言葉が出てこないことの方がむしろ稀であるほど、患者本人の要 望・社会的状沉そして価値基準を重要視すべきであるとの認識は世界的に広まってきてい る。しかしながら一方で、一般市民が日常生活の中で医療専門職と関わりを持つ際に「患 者中心」であることを実感しているかというと、必ずしも肯定的な意見ばかりが聞かれる 訳ではない。むしろ、解決すべき様々な課題が存在する。では何故、議論の高まりにも関 わらず「患者本位」には実践面において立ち遅れがあるのだろうか。

様々な理由が考えられるが、一つには、このようなスローガンについて明確な定義がな

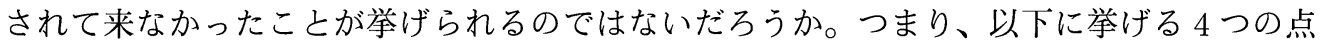
について、多くの国民のコンセンサスが得られるような状況には至っていない。第一に、 「患者中心」とは具体的にどのようなことを示しているのか、第二に、「患者本位」を実現 するために専門職従事者がなすべきことは何か、第三に、「患者本位」を実現するために 患者がなすべきことは何か、そして第四に、高度な医学の「専門知識」と、「患者中心」 というコンセプトは、どのように折り合いが付けられるのか、という点である。

一番目の問いについては突き詰めた議論が進められていないがために、「患者本位」と 
いうスローガンのみが繰り返されるだけで、実現・制度化のための具体的な方策が示され ることは極めて稀となっている。二番目の「専門職従事者がなすべきこと」については、 いわゆる ‘医療専門職論' (1) という枠組みの中で議論が行われてきているものの、三番目 の「患者がなすべきこと」という観点も引き入れて議論が深められているとは（筆者の知 る限り）言い難い状況にある。したがって第四の「医学の専門知識亡 ‘患者中心’ との折 り合い」について検討されることは皆無となっている。

この様な経緯の中にあって注目すべき展開が起きている。その一つがイギリス保健省と NHS (National Health Service : 英国国民保健サービス) (2)が主導する Expert Patient Programme（EPP)である。EPPは、慢性的症状のある人々のセルフ・マネジメント・ス キル育成を目的とした取り組みで、アメリカ合衆国のスタンフォード大学において開始さ れた患者の自助の為のトレーニングプログラム Chronic Disease Self Management Program (CDSMP)をモデルとしている(3)。これまでに、「セルフヘルプ」というコンセプトを揭げ、 当事者間の自助を目的とした取り組みは、英国や日本のみならず多くの国々で既に定着し ているものの、NHS の様な国の保健制度の枠組みの中で実施されている点において EPP は異なっていると言える。また「Expert Patient」という語が示す通り、患者を「専門能 力」の保持者として想定し、保健制度の中でその「専門性」を確立し活用していこうとす る点において、英国内のヘルスケア・サービス従事者、社会科学研究者をはじめとして、 多くの人々から注目を浴びる取り組みとなっている。

EPP は発足後 10 年に満たないが、評価チームによるレビューが進められてきている (National Primary Care Research and Development Centre, 2006)。このような評価の取り 組みは、主として医療者サイドから見たアウトカムに焦点が当てられているのが現状であ る。言い換えれば、EPP を社会科学研究として考察していく取り組みは未だ途上にあると 言わざるを得ない。

本稿は、「EPP の掲げる理念はどのようなものか? 」「EPP が強調する lay expertise（素 人の専門知識）とは、どのようなものとして記述されてきたか？」「今日に至るまで専門 家一素人の関係性はどのような認識がなされてきたか?」「EPP を通じて ‘素人専門家” の制度化が進められていくことが、既存の専門家一素人の関係性にどのようなインパクト をむたらしうるか?」という点について、NHSによる刊行物、その他 EPP に関わる諸文 献の記述を分析対象として、明らかにしていくことを目的としている。

はじめに EPP 発足の背景およびプログラムの概要について述べていく。その後、今日 に至るまで支配的である「素人 - 専門家」という二項区分について述べるともに、EPP が主唱する「素人専門家 (Lay Expert)」が、既存の「素人 - 専門家」観に及ぼす影響に ついて論じることとする。また、このような「非専門家」主導型のプログラムが内包する 問題点について明らかにしていく。

\section{The Expert Patient Programme とは}

\section{(1) 背景}

英国では 1990 年代から'patient partnership’（患者と専門職のパートナーシップ）とい う概念が求心力を持つようになって来ている（Gabe et al. 2003, Hasman et al. 2006）。これ は ‘患者主権” を求める声の高まりと、疾病構造の変化（慢性疾患患者の増加と、相対的 な急性疾患の割合の減少）という流れの中で、医師－患者間のヒエラルキーを解消し対等 
に意見交換を行うことにより治療を進めていくことを目指すむのである。NHS む、この 様な立場に立って、患者の持つ能力・経験等を何とか保健サービスに活用しようと取り組 み続けている。そうした取り組みの一つが EPPである。

プログラム推進のための最初のアナウンスは、1999年に英国保健省が発刊した 『Saving Lives: Our Healthier Nation』において示された。同書第 3 章には以下のような 記述がある。

糖尿病、関節炎、てんかんなどの慢性的症状を持つ人々は、自身の症状が悪化していく兆 候を敏感に察知する高い能力を有している。

(Department of Health 1999)

患者自身だからこそ持ちうる「専門能力」への理解の萌芽をここに見て取れる訳である。 そして、こうした「能力」の開発こそが 'patient partnership' ひいては「患者中心の 医療（patient-centred medicine）」を実現する道であると主張している。つまり、患者・ 医師双方が、異質ながらむ各々の「専門性」を備えた存在であり、“診察’の場を二人の 専門家（すなわち患者と医師）の間の協議の場であると想定している訳である。2001年 までに国内 26 ヶ所でトレーニングプログラムが実施され、今日に至るまでその取り組み は広がり続けている。2007 年までに、このプログラムを全国各地で実施出来る体制を整 備することが目標とされている。

\section{（2）プログラムの概要}

上述の通り EPP はNHS の主導のもと、関節炎や糖尿病などの慢性病を持つ患者が、自 分自身の病気について理解を深め、痛みや疲労に上手く対処する方法を学ぶために、2001 年に立ち上げられたトレーニングプログラムである。英国内を地区毎に分け、各地区を統 括するローカル・オフィスが設けられている。EPP の特徴の一つは「lay led (素人主導)」 のプログラムであることを前面に押し出している点である。トレーニングを指導する Tutor と呼ばれる指導員自身が、慢性疾患を抱える患者である。基本的に医師などの医療 専門職従事者がプログラムに介入することは無い。

プログラムへの参加資格は、慢性疾患がある者、または、その家族・介護者であること で、入会に当たっての審査・試験等は存在しない。トレーニングはグループ・セッション の形式をとり、指導員と参加者あわせ $4 \sim 8$ 人程度の規模で行われる。基本的に週一回 2.5 時間程度のセッションが 6 週間にわたって実施される。なお、先述の通りこの教本は EPP がモデルとしている米国の CDSMP において使用されている、Kate Lorig らスタンフォー ド大学の患者教育の研究グループが開発したメソッドに準拠している。トレーニングは教 本にある方法論に沿う形で進められ、原則として指導員が勝手に独自の解釈をし、プログ ラムに反映させることは認められていない。この点において、「lay-led (素人主導)」と標 榜している EPP が、どの程度「素人主導」であるのか、また、プログラムの本質が ‘ボ トムアップ’なのか ‘トップダウン’なのか、という問いが浮上してくるかもしれないが、 この点については次節以降で論じることとする。

プログラムは複数の項目から構成されており、主要なものとしては「Problem-solving (問題解決)」「Action plan（アクションプラン）」「Communication skills（コミュニケー ションスキル)」が挙げられる。一番目の「問題解決」では、慢性的な症状を抱えながら 
日常生活を送る上で問題となっていることを認識すること、そしてそのための解決の道筋 を、指導員やほかの参加者の助言を得ながら、自ら設定していくことが目標とされている。 二番目の「アクションプラン」は、参加者一人一人による目標設定と、その達成度の自己 評価からなる。例えば、精神的・身体的な問題により外出することに困難を感じる人が、 「週一回ショッピングや映画などに出かける」などの目標を自己設定し、宣言する。次週 のセッションでは、（指導員を含む）一人一人が、自己の目標をどの程度達成出来たか／ 出来なかったかを述へ、上手く達成出来ない時は、やはり指導員やその他の受講者の意見 を受けながら取り組みを改善していくことになる。この「アクションプラン」は、一番目 の「問題解決」と密接に結び付けられており、アクションプランを毎セッション（多くの 場合冒頭に）行うことにより、日常生活の様々な場面での自らによる問題解決を定着させ る狙いを持つ。三番目の「コミュニケーションスキル」は、慢性的症状と共に日常生活を 送る上での困難を軽減するために、他者とのコミュニケーションを効果的に活用し、問題 解決に役立てていくことを目指している。この場合の「他者」には、医師や看護師などの 医療専門職従事者も含まれており、このような人々との意思疎通に困難を抱えた現役患者 同士ならではの、実践的な対処方法が交換される。付け加えると、こうした内容こそが、 患者の「専門知識」とされているわけである。なお、専門職が持つものとして考えられて いる従来型の「専門知識」と、患者の「専門知識」との区分については、次節で述べる。

EPP のトレーニングプログラムを終えた患者は、その知識・スキルを他の患者へと伝え ていくことを期待されている。プログラムを終えた参加者のうち、指導員となるための認 定プログラムを受けた人は、その後、指導員として受講者の指導に当たる。また、指導員 としての技量・経験を認められると、Trainer（訓練員）として指導員の育成に当たる。

\section{EPP が提示する新たな専門家観}

EPP はどのような専門家（Expert）像を想定しているのだろうか。前章では EPP の概 要について述べたが、以下では、その理念について詳しく見ていきたい。はじめに、今日 に至るまで支配的な「専門家－素人」という二項区分式の認識のあり方について見ていく。 その上で、EPP が提示する新しい専門家観について述べていくこととする。これによって、 ヘルスケア領域で「専門家」に何が起きょうとしているのか、また、どのような「専門性」 が希求され始めているのか、という点を理解するための足がかりを示していきたい。

\section{（1）「素人一専門家」という二項区分}

一般に、患者は「エキスパート／専門家」とは対極にある存在と目されてきた。いわゆ る「医師一患者関係」という語が図らずも象徵しているように(4)、医師という医療の「エ キスパート」が関係の上位にあり、医師の指示を仰ぐことを患者の “定位置”とする見方 が今日もなお根強い。したがって、患者自身もしくはその家族が病気と向き合う過程の中 で、学習され獲得されたものが、“専門的な知識” と見なされることは稀であった。こう した状況下にあって EPP は新たな専門職観・専門知識観の提起をしている訳である。（以 下、専門職従事者が保有する ‘高度な’ 知識を指す、と考える伝統的な専門知識観と、 EPP が提起する新たな専門知識観を区別するために、前者を「専門職知識（professional expertise)」、後者を＜専門知識 $>$ と表すこととする。）

素人が獲得した知識が専門職知識であると規定されることは、IT の発達により医療情 


\begin{tabular}{|c|c|c|c|}
\hline \multicolumn{2}{|c|}{} & 知識獲得のプロセス & 排斥の根拠 \\
\hline \multirow{2}{*}{ 専門職知識との関倸 } & 同質 & $\mathrm{IT}$ ·専門家からの情報 & 知識の絶対量·資格の有無 \\
\cline { 2 - 4 } & 異質 & 疾病と向き合う過程·試行錯誤 & 「医学的裹付け」 \\
\hline
\end{tabular}

報へのアクセスが整備され、医学知識を獲得する機会が一般化してきている今日でも一般 的ではない。換言すれば、どれ程素人が医学的に「妥当な」情報を習得したところで「素 人知識」と称されることは少なくない。このことは、一面においては、素人の知識が「専 門」という範疇加ら排斥されていると見ることも出来る。これは二つの異なる水準で理解 出来るだろう。

医療機関で自分に処方された薬の概要や、自らの症状からどのような疾病を疑うべきか、 などといった事柄について確認するために、今日我々はインターネットや書籍などを参照 することで、容易に医学情報を得られるようになっている。実際に多くの患者がこのよう な学習作業を通して実質的な知識を獲得している。素人が得るこのような情報は、医学に 立脚していると目されている点において、専門職知識との関係性で言うと同質の関係に位 置する。しかしながら、いかに素人がこのような情報収集を繰り返したところで、知識量 および資格の有無という点に扔いて「専門」の範疇からは斥けられる（表 1) (5)。

また、自ら（または家族）の疾病と向き合う過程の中で得られたもの（e.g. 痛みを軽減 するための術、気持ちの持ち方、専門職との接し方など）む、通常、専門職知識とは見な されない。このような患者本人の学習成果は、往々にして慢性的な症状に対処するための 試行錯誤の中から生み出されるものの、例えば自らが糿余曲折を経て体得した独自の養生 法などは、必ずしも医師など専門家からの指導と合致するものではない。このような場合、 獲得された知識は、専門職知識とは異質のものであると見なされる。このような「素人知 識」は、「いかに本人の苦痛の軽減に役立っているか」「いかに患者当人が納得できるもの であるか」といった判断基準よりは、「科学的根拠を持つか」「医学的裏付けがあるか」と いう基準の下に「専門」という範疇からは排斥される。

このような一連の思考法は、言わば今日に至るまで支配的な「専門家－素人」観である と言えよう。表 1 が示すように、このような認識の本質には、第一に、素人もある程度の 医学知識を持つようになったが、知識量・体系的学習の欠如という点において「専門」の 領域には達していない、という見解が基盤となっている。第二に、患者は病気と向き合う 中で素人なりに様々なことを覚えるが、それらは必ずしも医学的裏付けを持つものではな いと学方が根底にある。

もっとも、今日に至るまでの医療社会学研究では、このような認識のあり方が問題視さ れて来ている。例えば Nettleton（1995:37）は、素人の健康観・疾病観は、単に専門家の 知識を薄めたものではない、と述べている。つまり、患者自身の社会的立場・文化的背 景・個人史などが、病と健康に関する当人の認識体系を形成しており、医学知識と同様に 治療の意思決定において重要なものであるとしている。Currer と Stacey（1986:1）は、 素人の考えはおしなべて「正しくない屯の」として規定される傾向があることを指摘して いる。 


\section{(2) EPPが示す專門家像}

EPP は、上記のような医学中心の「専門家一患者」モデルを脱し、「エキスパート」の 解釈を広げようとする意図を示してきた。保健省は 2001 年に発行した『The expert patient: a new approach to chronic disease management for the 21st century』の中で、患者 だけが持ちうる＜専門知識＞の活用の必要性を、以下の通り繰り返し述べている。

慢性疾患を持つ人々に対するヘルスケアサービスの提供を行っていく上で、患者の専門知 識（patient expertise）は不可欠の要素である、ということの認識を樑めていかなければな らない。

21 世紀に入り、NHS 改革が推進されている。そこでは、患者・専門職の双方が、 各々の専門の知識・能力を持っていることを前提とした上で、患者の支援を目指している。

(p. 11)

慢性疾患へのヘルスケアを効果的に行っていくことが求められているが、患者の専門知識 （patient expertise）は、ほとんど活用されてこなかった資源であると言える。（p. 33）

EPP では、患者を「ケアの受け手」と規定することを止め、逆に、臨床医とは異なるく 専門知識 >を保有する存在として捉えている。『The expert patient』（ibid. p1 1）では Coulter（2001）による患者之臨床医の専門知識区分（表 2）を援用しながら、素人の<専 門知識>への理解と、その活用を理念として揭げている。

表 2 を見てみると、Coulter（ひいてはこれを援用する EPP）が “患者”という存在を 規定する上で、「病の実体験者」「病の事実上の問題解決者」「専門知識を持つ者」という 性質を重要視していることが伺える。また、表 2 からは、患者の<専門知識 $>$ が患者当人 でなければ持ち得ないものであることが読み取れる。例えば「病の経験」については言う までもなく病を持つ者だけが得るものであるし、社会生活を営む全ての人が何らかの「社 会環境」に置かれているものの、そこに病が加わることでその社会環境は一変する。この 点は「価值観」「好み」にも当てはまる。言い換えれば、“専門職従事者が持ち得ていない むの’ として素人専門知識を規定しているわけであり、この点において、従来型の「専門 家一素人」観と大きく異なることが伺える。後ほど触れることになるが「ある人にとって は妥当であり、他の人にとっては当てはまらない」という、客観化を拒む性質があること 屯 EPP 流の<専門知識 >である。この点において様々な問題が予想されるところである が、これについては次章で扱うこととする。

以上のような「専門」に対する解釈の拡大から想起されるのは、今日、日本も含めて多 くの国々で実施されている「当事者主権」を主唱する様々な取り組みの本質についてであ る。すなわち、「患者中心」「当事者主権」等のスローガンを掲げる種々の取り組みが、上

表 2 患者と臨床医の専門知識区分

\begin{tabular}{|c|c|}
\hline 患者 & 臨床医 \\
\hline \hline 病の経験 & 診断 \\
\hline 社会環境 & 病因 \\
\hline リスクに対する心構え & 予後診断 \\
\hline 価值観 & 治療法の選択肢 \\
\hline 好み & 治療アウトカムの推定 \\
\hline (出典:
\end{tabular}


記のように当事者の知識・経験に積極的な評価をすることで ‘ボトムアップ’の流れを持 ち、文字通り当事者主導であるのか、あるいは逆に「患者中心」を標榜しながらも実際は トップダウン式に、「専門家」と目されている人々の持つ「知識」を単に「素人」に伝授 することに終始する（Bury 2004:52）ものであるか、という観点を私達に示している。も ちろん、トップダウンであるからと言って必ずしも問題があると言えるわけではなく、同 様に、ボトムアップだからと言って当事者に最良の結果をもたらすとも限らないことは、 確認しておかなければならない。問題なのは、「患者中心」「当事者主権」「セルフヘルプ」 などの言葉が、その取り組みの実質と乘離してひとり歩きするような事態である。

この様に、EPP が提起する新たなく専門家>像は、単に伝統的な専門家観の解釈を広げ て、今まで未活用のまま放置されてきた患者（及びその家族）という人的資源を活かして 行こうとするだけでなく、既存の「医療専門職一患者」間をめぐる諸相に対して新たな視 座を提供するものであることが分かる。

\section{4. 専門家観をめぐる諸問題}

\section{（1）制度的認証を得たものとしての「知識」}

上述の通り、素人が病を経験し、その対処を通じて獲得してきた情報が、専門職知識と 同一視されることは一般的ではない。このような獲得物は多くの場合「経験」または単に 「情報」更には「信念」として取り扱われてきた。Byron Good はこの「知識・知る (knowledge ・ know）－信念・思い込む（belief ・ believe）」という二項区分を問題関心 の中心に据え、相対視してきた研究者の一人であり、我々が「知識」の成り立ちについて 考える上で、有益な視座を提供している。Good（1994）はこの区分について説明する際 に、エイズの予防に関する以下の文章を引用している。

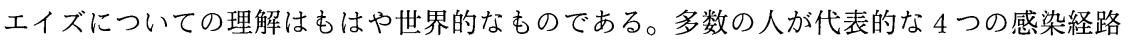
について知っている (know)。 約半数の人は蚊の媒介による感染、ワクチン、そしてエイ ズの完治などについて思い込み (believe)をしている。半数以上の男性がコンドームのこ とを知っている (know) が、コンドームの使用に対する消極的態度も広く見受けられる。 (Bertrand et al. 1991 cited in Good 1994:39、当該箇所の強調は Goodによる。)
}

$「$ 知る (know)」「知識 (knowledge)」という語が、「科学的」手順を経て「妥当」であ るとされ、社会的・制度的に認証されているものを指しているのに対して、「信じる (believe)」「信念（belief）」という概念はその対極にあり、制度的認証を得ていないもの として位置付けられている。今日、医療の領域で「エキスパート」と言う時、それは医学 等の専門職知識を修め、その能力・技術が制度的に認証された者に対して用いられる。こ こで重要なのは、この「制度的認証」という性質ゆえに、素人一専門家間の意見対立の解 決は、制度に依存せざるを得ないという硬直性である。Bury（2003:1）は、英国内で巻 き起こった三種混合をめぐる、素人 - 専門家間の近年の議論について記述している。この 予防接種を受けた後「自閉症になった」という事例報告が広がったことが原因で、親達は 混合ではなく選択的に一つ一つの予防接種を子供には受けさせることが好ましいと主張し たのに対し、数多くの医師と保健省は、三種混合が安全であり、受け入れられるべきであ るとする見解を再三表明し、要望の高まりをブロックしたという。こうした状況は、認証 を持たないグループ（この場合は親達）による何らかの要望の高まりが、制度的にも社会 的にも広がりを持ちにくいということを如実に物語っている。 


\section{（2）「知識」の “囲い込み’}

しかしながら、この二者（素人・専門家）の持つ知識に、果たして本質的な相違がある か、という点について、近年になってますます研究の関心が向けられて来ている。Arksey （1994）は、職場の反復動作が引き起こすとされる RSI（Repetitive Strain Injuries: 反復過 労傷害）が「疾病」として認知されるに至るまでの経緯について追跡調査していく中で、 専門家のみならず医学知識を持たない素人む、その言説構築過程に大きく関与してきたこ とを明らかにしている。つまり、医学知識をはじめとする「専門的な」知識は、必ずしも 専門家がその能力を以って導き出したものではなく、素人側からの積極的な ‘関与’があ ることを指摘しているわけである。

Arkseyによる ‘素人関与’ の指摘は、先に触れた制度的認証としての「専門性」が持 つ曖昧さ・一貫性の欠落を批判する上で有効な戦略の一つであると言える。しかしながら、 「専門知識」構築プロセスの核をなすもの、すなわち、何を是とし何を非とするかのゲー トキーピングの所在がどこにあるか、というポイントに立ち戻って社会学的考察をする時、 前節で述べられた ‘素人の知識の排斥' と上述の三種混合を巡る議論の展開から確認され る通り、素人の関与はあれども、やはり制度的認証を得た専門家集団のイニシアチブによ り情報の取捨選択が行われ、その上で成立しているのが近代から現代に至るまでの医療制 度であることが理解される。あえて 'lay expert' という語を用いなければならないことか らも、このことが理解できる。この意味では、Arksey の描写してきた一連のプロセスは、 それまで制度的認証を得ることのなかった「素人」によって表明された見解が、ある局面 では排斥されながら、別の局面においては、「専門」の領域に囲い込まれてきた経緯であ ると見るべきであろう。

素人の関与を決して過大に受け取るべきではないにしても、Arksey の指摘は、従来 「専門の」知識とされてきたものの暧昧な成り立ちを理解する上で有益な視座を示してい る。“素人専門家” という語自体が、従来の「専門家－素人」二項区分においては、矛盾 を持つものでしかないが、元来「専門」とされてきたもの自体が、必ずしも厳密な素人一 専門家の区分に基づいて築き上げられてきたものではない。この点において、社会におい て何らかの制度的認証を持つ「専門性」を構成するプロセスを理解する際に、素人を排除 して考えることの方が、むしろ整合性を欠いていることが分かる。

\section{（3）「素人主導（Lay-led）」が直面する問題}

知識の制度的認証という側面に触れ、素人知識を囲い込んだものとしての専門職知識と いう点を見てきた。ここまでの記述で既に明らかなように、EPPには、こうした「専門家」 「専門知識」の成り立ちに対する異議申し立てという側面がうかがえる。しかしながら、 EPP の実際の運営体制について考察したときに、実際にはそれほど単純な図式が当てはま る訳ではないことが明らかとなる。

第一に、先述の通り EPP は、トレーニングという作業を通して “指導員”から 高講 者’にスキルが伝授されるという形式を取っている。もちろん、いわゆるレクチャー形式 によって ‘上から下に” 知識を教え込むわけではなく、自発性を重んじた上で「セルフ・ マネジメント」を促すことが大原則であると教本は述べている（NHS Expert Patient Programme, 2002)。しかしながら、片や ‘マスターした者”である指導員が存在し、あう 一方に “未だマスターせ媎”として受講者がいる以上、全くフラットな関係性の ‘専門 
家の集まり’ としてセッションを捉えることは出来ない。もし「持てる者」から「持たざ る者」へ、という知識の伝達の方向が固定化されるとすると、いかに素人専門知識（lay expertise）の概念が掲げられたとしても、知識の保有量をべースとした新たな上下関係が 創出される可能性が考えられる。Finger と Asún（2001:10）はイヴァン・イリッチの専 門職化（professionalization）に関する議論を踏まえ「専門家の存在、そして専門家を必要 とする文化は常に、更なる専門家を要請する」と述べている。その理由として、

1. 専門家（expert）は組織化することにより、その存在自体が「制度的障壁（institutional barricades)」となる

2. その結果、知識の生産を全面に渡ってコントロールするようになり、『どの様な知識が 妥当であるか」「その知識がどの様にしたら獲得できるのか」「ての人が知識を獲得し ているかどうか」などを ‘判定する’ 権限を付与される

としている。この様な ‘専門家再生産システム’ とも呼ぶべき構造ゆえに、EPPをはじ めとする ‘当事者中心’を揭げるプログラムが、その内部において、当事者間の新たな七 エラルキーを作り出す可能性を持つことをここで指摘しておかなければならない。

第二に、プログラムの中で参加者の個別性がいかに尊重されたとしても、「(課程修了者 の）認定」「育成」「教本」という性質・制度がその基盤にあるのであれば、「正しい」知 識を伝達し「そうでないもの」を排除することが営みの本質とされることは十分に考えら れ、結果的にそのプログラム自体が矛盾を持つものとなる。何故なら、前掲の表 2 「専門 知識の共有」に関連して既に述べたとおり、患者の専門知識（lay expertise）として考え られているものは、本質的に「正しい／間違っている」という区分を持つものではなく、 ある人にとっては有効であり、別の人にとっては当てはまらない、という性質のものだか らである。別の言い方をすれば、素人の専門知識（lay expertise）は必ず本人の取捨選 択・価值判断を要求するということである。

この様に EPP は、理念レベルでは「素人の専門知識」という新たな可能性の提示とそ の活用を主唱している一方で、プログラムの成り立ちは必ずしもこの理念を具現化するも のとは言えず、素人専門家の制度化のための実践面では、未だ伝統的な専門家観が基盤に あることが分かる。

\section{5. 結語}

EPP が提示する新たな専門家像は、何らかのトレーニングを受けた者や資格を取得した むの者に留まらず、日常生活における困難に対処する秀でたスキルを自ずと身に付けた者 をも含めており、「専門知識」を持つ主体を大幅に拡大させていることが理解出来た。し かしながら、ヘルスケアという領域の特性（国家の制度的枠組を必要とし、「客観的判断 基準」と「専門性」に対する制度的保障を要求する）のため、「患者は誰でも専門家であ る」とする見解が、そのまま社会的・制度的に許容されるわけではない。結果として「素 人も専門知識を持っている」と標榜しながらも、「持つ者＝指導員」から「未だ持たざる 者 $=$ 受講者」への知識授受プロセスを経て、「正しい／正しくない」という二項区分を部 分的にせよ内包しながら、資格授与へと至る従来型の専門家養成の手続きを取らざるを得 ない状況がある。

EPP に関する文献の記述から、「lay expertise（素人専門知識）」は、「正しい／正しくな い」という二項区分を基盤とせず、“ある人にとっては妥当であり、他の人にとっては当 
てはまらない’という本質を持つものであることが読み取れた。重要なことは、こうした 「素人専門知識」の本質ゆえに素人専門家を普及させる試みは、統一化・客観化を伴わな ければならない現代の ‘制度化’ という作業とは相容れず、この点が素人専門家の制度化 というプロジェクトのジレンマとなっている。

EPP が提示してきた新たな専門職観を見てきたことで、従来型の「専門職－素人」観に ついて我々が再確認出来ることがある。それは、ここまで読み進んだ段階ですでに明らか なように、今日に至るまでの「専門家判断」は統計的判断であり、言い方を換えれば、 “比較的多数”を根拠として「有意」であるとする価值判断である、ということである。 ここで重要なことは、こうした状況の良し悪しを論じることではなく、このような価值判 断では拘束しきれない事項への配慮、対応策の検討なのである。この意味において、「正 しい/正しくない」の二項区分・客観化というコンセプトでは括れないものを、いかにし て制度化に結び付けられるか、という問いに取り組んでいく作業は重要性が認められるわ けである。今後、素人主導（lay-led）を標榜する取り組みは我が国においても広がりを見

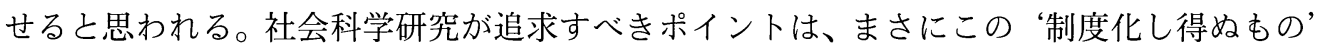
を制度の中で保護・活用するための必要条件に他ならない。

註

（1）医療専門職論は、いわゆる「専門家支配論（professional dominance)」(Freidson, 1970a; 1970b）に 代表されるように、専門職批判に比較的多くの労力を注いできた。しかしながら、専門職批判という 観点が強い一方で、その専門サービス利用者たる患者まで考察の対象に引き入れて専門職のあり方を 模索する議論は未だ途上にあると言える。「アクティブ・ペイシェント」「エキスパート・ペイシェン 卜」という語の出現が象徴するように、患者一般の自律的行動と知識レベルは今日、飛躍的に向上し ており、専門職論はそのスコープを変化・多元化する時期に来ていると言える。

（2）NHS は国家の税収入の中から運営費が捻出される国民保健医療サービスであり、サービスの管理全 般は、英国保健省（Department of Health）の統轄下にある。

（3）「モデル」と述べたが、EPP は CDSMP とほぼ同一のメソッド・教本を採用している。ただし、英国 内の様々な諸事情を鑑みて、米国のオリジナルとは若干異なる内容へと微調整が施されてきている。 なお、モデルとなっている米国版では「Expert Patient」という名称は用いられておらず、英国にお いてこのようなコンセプトが前面に押し出されるに至った。

（4） Bury（2004:48）によれば「医師－患者関係（doctor-patient relationship）」という語自体が、修辞的 技巧（rhetorical device）となり、「医師－患者間には何らかの特別な関係性がある」「医師はその職 能により、特権的立場にある」などの考えを暗示する可能性があり、ひいては、「治療における他の 専門職からの超越性・優越性」を堅持させることに関与しうると指摘している。

（5）日々報告される医学的「発見」により、医学の「常識」は絶えず塗り替えられてきており、数年前に 一般的であった医療実践が別のものに取って代わられることは珍しくない。この点において、知識の 絶対量が持つ優越性は薄らいでいる（松繁 2006）という側面が理解される。

付記

本研究は財団法人 医療科学研究所の助成による研究の一部である。

\section{文献}

Arksey, H. 1994 'Expert and lay participation in the construction of medical knowledge' Sociology of Health and Illness. 16, 4.

Bury, M. 2003 'A commentary' Perspectives on the expert patient. Presentations from a seminar held at the 
Royal Pharmaceutical Society of Great Britain on 19th May. [Internet] Available from 〈http://www.rpsgb.org.uk/pdfs/exptpatsemrept.pdf〉 [Accessed July 21, 2006]

2004 'Researching patient-professional interactions' Journal of Health Services Research and Policy Vol 9, Suppl 1 January.

Coulter, A. 2001 Research and Values: Consumer Participation, Picker Institute. [Internet] Available from 〈http://www.healthservicesconference.com.au/presentations/a_coulter.pdf [Accessed July 21, 2006]

Currer, C. and Stacey, M. (eds.) 1986 Concepts of Health, Illness and Disease: a comparative perspective Leamington SpaBerb.

Department of Health 1999 Saving Lives: Our Healthier Nation. London, The Stationery Office. 2001 The Expert Patient: a new approach to chronic disease management for the 21st century. London.

Finger, M. and Asún, J. M. 2001 Adult Education at the Crossroads: Learning our way out. London: Zed Books.

Freidson, E. 1970a Profession of Medicine: A Study of the Sociology of Applied Knowledge. Harper Row, New York.

1970b Professional Dominance: The Social Structure of Medical Care. Atherton Press, New York.

Gabe, J., Olumide, G., and Bury, M. 2003 'It takes three to tango: a framework for understanding patient partnership in paediatric clinics' Social Science and Medicine 9, 35.

Good, B. J. 1994 Medicine, Rationality, and Experience: An Anthropological Perspective. Cambridge, University Press.

Hasman, A., Coulter, A. and Askham, J. 2006 Education for partnership: DEVELOPMENTS IN MEDICAL EDUCATION. PICKER INSTITUTE EUROPE.

National Primary Care Research and Development Centre 2006 Process Evaluation of the EPP-Report II. National Primary Care Research and Development Centre.

Nettleton, S. 1995 The Sociology of Health and Illness, Polity, Oxford.

NHS Expert Patient Programme 2002 Self-management of Long-term Health Conditions: A Handbook for People with Chronic Disease. Bull Publishing Company, Colorado.

松繁 卓哉 2006 “医学教育に抢ける problem-based learning (問題中心型学習) の導入：医師の「専門性」 構築プロセスについての考察’『保健医療社会学論集』第 17 巻 1 号.

（立教大学大学院社会学研究科社会学専攻・博士後期課程 